\title{
Effect of zinc supplementation on reproductive performance of Teressa goat
}

\author{
M. S. Kundu, Arun Kumar De, S. Jeyakumar, Jai Sunder, A. Kundu and T. Sujatha
}

Division of Animal Science,

Central Island Agricultural Research Institute, Port Blair, Andaman and Nicobar Islands-744101,India

Corresponding author: M. S. Kundu, email: mkundu47@rediffmail.com, Phone: +91-9474290668

AKD: biotech.cari@gmail.com, SJ: jeyskumarsakthivel@gmail.com, JS:jaisunder@rediffmail.com, AK: drakundu1@yahoo.com, TS: drsujathaars@rediffmail.com

Received: 15-03-2014, Revised: 03-05-2014, Accepted: 07-05-2014, Published online: 07-06-2014

doi: $10.14202 /$ vetworld.2014.380-383

How to cite this article: Kundu MS, De AK, Jeyakumar S, Sunder J, Kundu A and Sujatha T (2014) Effect of zinc supplementation on reproductive performance of Teressa goat, Veterinary World 7(6):380-383.

\begin{abstract}
Aim:The present study evaluates the effect of dietary zinc supplementation on reproductive and productive performance of Teressa goat, an indigenous species of Andaman and Nicobar Islands.

Materials and Methods: Eighteen female goats were randomly divided into 3 groups of 6 animals each; (A) control with basal ration without any zinc supplementation (B) Treatment 1 with basal ration supplemented with 50 ppm zinc oxide (C) Treatment 2 with basal ration supplemented with $100 \mathrm{ppm}$ zinc oxide. Different reproductive parameters, e.g. numbers of days to oestrus, the incidence of oestrus, pregnancy rate, kidding rates and weight of kids were recorded.

Results: Data indicated that the supplementation of different levels of inorganic zinc oxide significantly increased the incidence of oestrus $(33 \%)$, pregnancy rate $(12 \%)$, kidding rate $(5 \%)$ and resulted in shorter onset (8 days) of oestrus as compared to the control. The mean body weight and daily weight gain of kids born to supplemented does were significantly $(\mathrm{p}<0.05)$ higher than the kids born to control.
\end{abstract}

Conclusion: The supplementation of 50 to $100 \mathrm{ppm}$ zinc oxide to the basal diet of Teressa goat significantly improved different productive and reproductive parameters.

Keywords: Andaman and Nicobar islands, fertility, reproduction, Teressa goat, zinc.

\section{Introduction}

Trace elements are needed for vitamin synthesis, hormone production, enzyme activity, energy production and other physiological processes related to growth, reproduction and health [1]. Deficiency of trace elements affects almost all physiological processes like growth, reproduction, immunity, milk production and other processes of animals. Histological sections of organs also showed their ultrastructural changes due to the elemental deficiencies [2]. Zinc is a very important trace element that is involved in a wide range of metabolic activities and productive performances like growth [3], reproduction [4] and humoral immune system [5]. Maternal Zinc deficiency may compromise infant development and lead to poor birth outcomes [6]. The trace elements status in general and Zinc in particular of new-born depends on maternal transfer via the placenta, the colostrums or the milk $[5,7]$. Forages are the main source of Zinc for the goats but its contents in forages are very variable; so that when the mineral supplementation is insufficient, animals suffer from several deficiencies. Under field conditions, the bioavailability of $\mathrm{Zn}$ is influenced by interactions with other trace elements like $\mathrm{Ca}, \mathrm{Cd}, \mathrm{Ni}$, and phytic acid, which can induce a secondary Zn-deficiency even if their intake is high[2].

Copyright: The authors. This article is an open access article licensed under the terms of the Creative Commons Attribution License (http://creativecommons.org/licenses/by/2.0) which permits unrestricted use, distribution and reproduction in any medium, provided the work is properly cited.
Teressa goat is an indigenous species of Andaman and Nicobar Islands. The name 'Teressa' have been coined from the Island Teressa, a unique Island among Nicobar group of Islands. The Island is unique in the sense that it has plenty of grasslands whereas other Islands of Nicobar group are covered by tropical rain forest and coconut plantation. This unique topography makes this Island very much feasible for goat rearing. From the original breeding tract of Teressa Island, the breed has scattered to adjoining small Islands like Hut bay, Little Andaman etc. The breed is tall and sturdy; colour varies from brownish to dark tan with white and black patches. The most prominent feature of the breed is the presence of a white patch or line starting from inner canthus of both eyes or from eye brows and extending up to nostrils or mouth [8]. The adult weight ranges from 55 to $70 \mathrm{~kg}$. At present the population of goat in the Nicobar district is only 8357 [8]. Teressa goats are reared mainly for meat purpose.

Reproductive problems are common among the dairy animals of Andaman and Nicobar Islands [9]. Lower levels of macro and micro minerals were reported in blood serum of dairy animals which might be the major cause of reproductive problems [10]. Moreover, the soil, grass and water of Andaman and Nicobar Islands are reported to be deficient in micro and macro minerals particularly $\mathrm{Zn}$ and $\mathrm{P}$ [11]. The Teressa goats are reared mostly under free range system and their feed consists of grass, coconut leaves, tree fodders, dried coconut and oil extracted coconut as 
Table-1: Effect of zinc supplementation on the reproductive performance of Teressa goat.

\begin{tabular}{lccc}
\hline Reproductive parameters & Control $(\mathbf{n = 6 )}$ & Treatment 1 (n=6) (50 ppm ZnO) & Treatment 2(n=6) (100 ppm ZnO) \\
\hline \% Oestrus response (number) & $66.66(4)^{\mathrm{b}}$ & $83.30(5)^{\mathrm{ab}}$ & $100.00(6)^{\mathrm{a}}$ \\
\% Onset of oestrus in days & $25.30 \pm 0.42^{\mathrm{a}}$ & $20.40 \pm 0.37^{\mathrm{ab}}$ & $17.70 \pm 0.34^{\mathrm{b}}$ \\
Pregnancy rate (number) & $50.00(3)^{\mathrm{b}}$ & $66.66(4)^{\mathrm{ab}}$ & $100.00(6)^{\mathrm{a}}$ \\
Kidding rate (number) & $87.50(3)^{\mathrm{b}}$ & $90.90(4)^{\mathrm{ab}}$ & $91.70(5)^{\mathrm{a}}$ \\
Fecundity & 1.66 & 2.00 & 2.40 \\
\hline
\end{tabular}

Values are presented as mean \pm SEM, Values in the same row with different superscripts $(a, b)$ vary significantly $(P<0.05)$.

Table-2: Effect of zinc supplementation on the production performance of kids up to two months of age

\begin{tabular}{|c|c|c|c|}
\hline Production parameters & Control $(n=6)$ & Treatment 1 (n=6) (50 ppm ZnO) & Treatment 2(n=6) (100 ppm ZnO) \\
\hline No. of kids born & $4(66.66)^{b}$ & $5(83.3)^{a b}$ & $6(100.0)^{a}$ \\
\hline Weight $(\mathrm{kg})$ at birth & $1.68 \pm 0.05^{b}$ & $1.79 \pm 0.04^{a}$ & $1.78 \pm 0.06^{a}$ \\
\hline Weight $(\mathrm{kg})$ at two months of age & $5.10 \pm 0.30^{b}$ & $5.91 \pm 0.29^{a}$ & $5.87 \pm 0.09^{a}$ \\
\hline Body weight gain $(\mathrm{kg})$ & $3.43 \pm 0.26^{b}$ & $4.11 \pm 0.27^{\mathrm{a}}$ & $4.09 \pm 0.08^{a}$ \\
\hline Body weight gain at $1^{\text {st }}$ month ( $g /$ day) & $59.17 \pm 5.16$ & $73.13 \pm 4.39$ & $68.06 \pm 1.82$ \\
\hline Body weight gain at $2^{\text {nd }}$ month ( g/day) & $55.00 \pm 12.66$ & $63.96 \pm 11.15$ & $68.20 \pm 2.15$ \\
\hline
\end{tabular}

Values are presented as mean $\pm S E M$, Values in the same row with different superscripts $(a, b)$ vary significantly $(P<0.05)$.

per the availability in the area. No supplemental feeding is given to explore the potentiality of the unique indigenous species.

Due to limited information on factors relating to reproductive performance of goats under range conditions, the present study was undertaken to investigate how zinc supplementation affected reproductive events and kidding rate of goats kept under extensive conditions. The findings of this study will be helpful to design measures to increase the reproductive efficiency of this breed which in turn will enable the indigenous tribal population to effectively harness the potential of this goat breed.

\section{Materials and Methods}

Ethical approval: The present experiment complies with all relevant institutional and national animal welfare guidelines and policies. Approval from the Institutional Animal Ethical Committee was taken prior to the experiment.

Animals and experimental design: Eighteen Teressa goats of first and second lactation and aged 3 - 4 years, weighting about $25 \mathrm{~kg}$ were used in the present study. All does (She goat) were found healthy with no external and internal parasites. Does were provided with night / rain shelter with open paddock. Animals were maintained on grazing and fed with looped fodder. The basal diet in this experiment contained natural grass pasture and lopped fodder available in the area normally grazed by the goat. The proximate composition of the natural grasses was $87.54 \%$ OM, $12.46 \%$ Ash, 10.70\% CP, 1.98\% EE, 24.55\% CF and 49.69\% NFE, besides containing 12.3 ppm Zn. The pregnant animals were offered one coconut (average weight of each coconut is $200 \mathrm{~g}$ ) during the last month of the pregnancy. The treated groups were supplemented with a standard mineral mixture consisting of: Dicalcium phosphate (60\%), Sodium chloride (17.5\%), Chalk Powder (20\%) and Zinc Oxide (2.5\%). The basal diet contained $22.1 \mathrm{mg} \mathrm{Zn} / \mathrm{Kg}$ whereas mineral mixture contained $20 \mathrm{mg} \mathrm{Zn/gm}$. The animals were randomly divided into three groups of 6 does each. Group 1 (Control) was kept as a control and was fed the basal diet. Group 2 (Treatment 1) received basal diet supplemented with 50 ppm zinc oxide ( 50 ppm $\mathrm{ZnO}$ ) whereas Groups 3 (Treatment 2) was fed the basal diet supplemented with $100 \mathrm{ppm} \mathrm{ZnO}$. The does were orally supplemented with 2 gm and 4.5 gm prepared mineral mixture /head /day respectively for the treated groups. The experiment was continued for 6 months.

Reproductive performance: The animals were observed for oestrus symptoms every day between 9 AM-12 AM and 2 AM-5 PM using castrated buck. Standing condition of does was considered to be in oestrous when mounted by a buck. Oestrus does were naturally bred. Reproductive traits like oestrus response, the time interval to onset of oestrus, pregnancy; kidding rates and fecundity were recorded.

Performance of kids: New born kids were numbered and weighed just after birth and colostrums were fed to the kids. Fortnightly body weights were taken up to 2 months of age to determine the body weight gain.

Statistical analysis: The differences between treatments were analyzed using a one way analysis of variance (ANOVA). Differences with a confidence level of 0.05 or less were considered to be significant. All the data collected were analyzed [12].

\section{Results}

The different reproductive performance parameters like oestrus response, onset of oestrus, pregnancy and kidding rates, for control and supplemented groups are presented in Table-1. Both the supplemented groups showed significantly $(\mathrm{P}<0.05)$ higher incidence of oestrous than the control groups. Does that received $100 \mathrm{ppm} \mathrm{ZnO}$ showed early oestrous symptoms (17.7 \pm 0.34 days $)$ than control $(25.3 \pm 0.42$ days $)$ and $50 \mathrm{ppm}$ 
group (20.4 0.37 days). Similarly supplemental effects have been recorded with regard to pregnancy rate and kidding rates. Does that received $100 \mathrm{ppm}$ $\mathrm{ZnO}$ showed significantly $(\mathrm{P}<0.05)$ higher pregnancy $(100 \%)$ rate followed by $50 \mathrm{ppm}$ group $(66.66 \%)$ and the control group $(50.00 \%)$. Significant higher kidding rates were recorded in supplemented groups than the control group.

The number of kids born and their weight at birth were significantly $(\mathrm{P}<0.05)$ higher in does supplemented with $50 \mathrm{ppm}$ and $100 \mathrm{ppm} \mathrm{ZnO}$ than the control group (Table-2). The total body weight gain of kids at two months age was significantly $(\mathrm{P}<0.05)$ improved in the group supplemented with $50 \mathrm{ppm} \mathrm{ZnO}$ (5.91 $0.29 \mathrm{~kg})$ and $100 \mathrm{ppm} \mathrm{ZnO} \mathrm{(4.09 \pm 0.08)} \mathrm{as} \mathrm{compared} \mathrm{to}$ control.

\section{Discussion}

Small ruminants including goat play an important role in the livelihood of small and marginal farmers and maintenance of subsistence agriculture. Normally goat is considered as poor man's cow. The farmers keep goat for sale, consumption and personal use. Teressa goat is generally reared by the tribal farmers of Nicobar group of islands and it is an integral part of their tradition and culture. The farmers do not rear goats for commercial purposes and slaughter them for domestic consumption during different festivals, sports or community functions. Sale of goat meat among the tribes is considered as $\sin$. The productivity especially reproduction of goats in subsistence agriculture can be affected by nutrients availability and especially by the mineral content of the forage resources on the rangeland [13]. Inadequacy of year-round feed resources is also another cause of low animal production in arid and semi-arid regions [14]. So, dietary deficiencies of copper $(\mathrm{Cu})$, selenium $(\mathrm{Se})$ and zinc $(\mathrm{Zn})$ are commonly seen in ruminants [4].

The results of the present study showed that the $\mathrm{Zn}$ supplementation had beneficial effects on the reproductive performance of the Teressa goat as indicated by higher incidence of oestrous and early oestrous symptoms (Table-1) which is in agreement with reports in cattle where $\mathrm{Zn}$ supplementation $(0.8 \mathrm{~g} /$ day/animal $)$ improved onset of oestrus [15] and improved reproductive performance [16]. Ewes receiving zinc supplementation had a higher fertility rate and were more prolific ( $89 \%$ vs. $40 \%$ ) [17]. On the other hand, goats fed on diets of low Zn had low conception rates and prolificacy [18].

Significantly higher body weight at birth as well as number of kids born from dams receiving supplementation with 50-100 ppm Zn as compared to those of control has been recorded in our result (Table- 2). The result of the study is consistent with the findings in ewes where supplementation of $100 \mathrm{ppm} \mathrm{Zn} \mathrm{improved}$ the litter size of does, body weight of lambs at birth (4.0 vs. $2.9 \mathrm{~kg}$ ) and at weaning (17.7 vs. $14.2 \mathrm{~kg}$ ) as compared to ewes that were fed control diet containing 23-25 ppm Zn [17]. Average daily gain and feed efficiency improved significantly with $\mathrm{Zn}$ supplemen-tation in lambs as compared to controls $[19,20]$. Feeding a high concentration of $\mathrm{Zn}$ to the ewes helps to increase zinc concentration in the whole milk [21]. The lambs that consumed milk containing high level of Zinc also showed higher body weight gain at weaning [22]. In the present study, similar findings were observed. Therefore, in order to improve the reproductive perfor-mance of Teressa goat, dietary supplementation of $\mathrm{Zn}$ at 50 or 100 ppm is highly recommended.

\section{Conclusion}

From the results presented above, it could be concluded that supplementing 50 to $100 \mathrm{ppm}$ zinc oxide to the basal diet of Teressa goat significantly improved the reproductive and productive performance.

\section{Authors' contributions}

MSK, JS, SJ and AK were involved in design of the study. The experiments were done by MSK, TS and JS. $\mathrm{AK}$ and AKD revised the final draft of manuscript. All authors read and approved the final manuscript.

\section{Acknowledgements}

The authors are thankful to the Director, Central Island Agricultural Research Institute, Port Blair, ICAR Reference section for providing funds for this study.

\section{Competing interests}

The authors declare that they have no competing interests.

\section{References}

1. Hayat, H. M., Howeda, M. A. and El-Wakeel, A. S. (2010) Effect of zinc methionine supplementation on reproductive performance, kid's performance, minerals profile and milk quality in early lactating Baladi goats. World Appl Sci J., 9: 275-282.

2. Haenlein, G.F.W and Anke, M. (2011) Mineral and trace element research in goats- A Review, Small Rumin Res, 95: 2-19.

3. Underwood, E. J. and Suttle, N. F. (1999) In: The mineral nutrition of livestock, 3rd ed. CABI Publishing, CAB International, Wallingford, Oxon, UK. Technology 93: 193203.

4. Abdel Monem, U. M. and El-Shahat, K. H. (2011) Effect of different dietary levels of inorganic zinc oxide on Ovarian activities, Reproductive performance of Egyptian Baladi ewes and growth of their lambs. Bulgarian J Vet Med., 14 (2): 116-123.

5. Prasad, T and Kundu, M.S. (1995) Serum IgG and IgM responses to sheep red blood cells (SRBC) in weaned calves fed milk supplemented with $\mathrm{Zn}$ and $\mathrm{Cu}$. Nutrition 11:712-715.

6. Ian Darnton-Hil.1 (2013) Zinc supplementation during pregnancy. e-Library of Evidence for Nutrition Actions (eLENA). http://www.who.int/elena/bbc/zinc_pregnancy/ en/ Accessed on 15.2.2014.

7. Enjalbert, F. (2009) The relationship between trace elements status and health in calves. Revue. Méd.Vét. 160 (8-9): 429435 .

8. Kundu,A., Sunder,J., Jeyakumar,S., Verma, S.K., Kundu,M.S., De,A.K. and Srivastava,R.C.(2010) Livestock and poultry production policy for Andaman and Nicobar Islands: A scientific perspective. Published by Director, CARI, Port Blair. p1-48. 
9. Jeyakumar,S., Kundu, A., Jaisunder, Balakrishnan, M., Kundu, M.S., Sujatha, T., Verma, S.K. and Srivastava, R.C. (2012) Diversity and conservation of farm animal genetic resources (FAnGR) of Andaman and Nicobar Islands. In: Ecology of Faunal communities on the Andaman and Nicobar Islands. Edited by Venkatarnman, K., Ranghunathan, C., Sivaperuman,C. Springer : 313-336.

10. Jaisunder, Rai, R.B., Yasmeen,J., Kundu,A. and Jeyakumar,S. (2007a) Mineral status of infertile cattle of Andaman. Indian J Anim Sci, 77(11): 1135.

11. Jaisunder, Rai, R.B., Yasmeen,J., Kundu, A. and Jeyakumar,S. (2007) mineral profile in soil, grass, water and cattle blood of South Andaman's. Indian J Anim Sci, 77 (11): 1103-1107.

12. Snedecor,G.W. and Cochran,W.G. (1994) Statistical Methods, $9^{\text {th }}$ edn., Iowa state Univ.Press,Ames, U.S.A. p156159.

13. Vázquez-Armijo1, J. F., Rojo1, R., Salem1, A.Z.M., López1, D., Tinoco 1, J. L., González, A., Pescador, N and Domínguez -Vara, I. A. 2011.Trace elements in sheep and goats reproduction-A Review. Trop Subtrop Agro Ecosystems., 14:1-13.

14. Kawas, J.R., Andrade-Montemayor, H., Lu, C.D.( 2010) Strategic nutrient supplementation of free-ranging goats. Small Rumin Res., 89: 234-243.

15. De, Kalyan., Pal, S., Shiv Prasad and Dang, A.K. (2014) Effect of micronutrient supplementation on the immune function of crossbred dairy cows under semi-arid tropical environment. Trop. Anim. Health Prod. 46:203-21.

16. Phiri, E. C. J. H., Nkya, R., Pereka, A. E., Mgasa, M. N. and
Larsen, T. (2007) The effects of calcium, phosphorus and zinc supplementation on reproductive performance of crossbred dairy cows in Tanzania. Trop. Anim. Health Prod. 39:317-323.

17. Ali, H.A., Ezzo, O.H., El-Ekhnawy, K.E., 1998. Effect of zinc supplementation on reproductive performance of Barki ewes under practical field condition. Vet. Med. J. Giza. 46: 77-87.

18. McDowell, L.R., Valle, G., Rojas, L.X., Velásquez-Pereira, J. (1997) Importancia de la suplementación mineral completa en la reproducción de vacas. In: XXXIII Reuniónnacional de investigaciónpecuaria, XXIII Simposium de ganadería tropical: Interacciónnutriciónreproducción en ganadobovino, Veracruz, México. p31-47.

19. Fadayifar, A., Aliarabi, Hassan., Tabatabaei, M. M., Zamani, P., Bahar ,A., Malecki, M. and Dezfoulian, A. H. (2012) Improvement in lamb performance on barley based diet supplemented with zinc. Livest Sci., $144:$ :285-289.

20. Abedelrahman, M. M., Al-Rayyan, N. A. M., Awawdeh, F. T. And Alazzeh, A. Y. (2003) The effect of dietary levels of zinc-methionine on the performance of growing Awassi lambs. Pak. J.Biol. Sci., 6: 979-983.

21. Hermansen, J. E., Larsen, T and Andersen, J. O. (1995) Does zinc play a role in the resistance of milk to spontaneous lipolysis? Int Dairy J., 5: 473-481.

22. Grag, A. K., Mudgal, V and Dass, R. S. (2008) Effect of organic supplementation on growth, nutrient utilization and mineral profile in lambs. Anim Feed Sci Technol., 144: 8296.

$* * * * * * * *$ 